\title{
學 會
}

\section{第 20 回日本醫科大學醫學會}

期

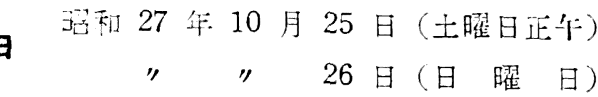

講 演 抄 録

（1）筋 色

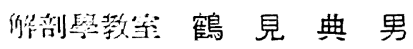

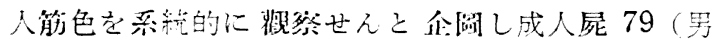
$6 \overline{0}$, 女14), 胎兒殒 29 について全子比色計を用いて測 定したもので、こ机を汴の如く概述する。

筋色は 22〜41 藏で基礎色品も高く，この時期を誕 點として低年龄或は高年峈合になるに從い次第に低くな る。色調の分析各念有量中, 黑念有量は加路会之其に增 施し，就色・白含有量は減少する。

六于は男子に比して基礎色低く, 純色・黒含有量は 減少している。部位的戀化は, 下腰部が基礎色最も高 く、等部これに次き，四抆にあつては上腕・大腿部が 高い。こ礼らはまた黒・純色念有量が多い。乳部・局 甲下部は基礎色低く，白含有量が多い。

背側は腹側よりも全般に基礁色高く, 黑・純色含有 量が多い。

胎兒屍筋色は成人のものに比して甚礁色低く, 白合 有量が傢れている。また各部位斿色の戀移は成人と買 つて, 軀㲦が四肢よりも基礁色高く, 黑・純色含有量 3:多い。

月数別に觀祭すると, 月数の增加と共に基礎色は高 变り，黑・純色含有量は增加する。5ケ月ょり 8 ケまま この變移と 8 ケより10ケ月までの繸移を此較すると

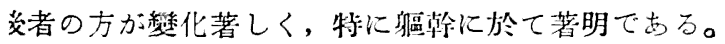
組織學的藋察については別の機會にゆずる。

\section{（2）回盲部動脈及び虫垂の形態}

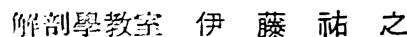

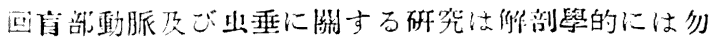

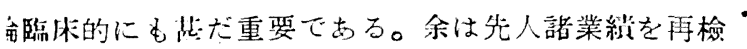
ナないしはその空虚を衫うため榆索を級けている。令

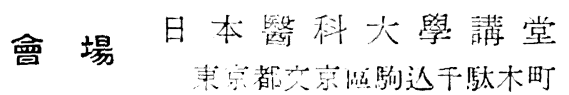

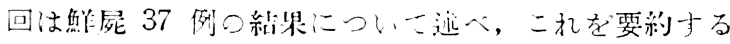
上次の如くなる。

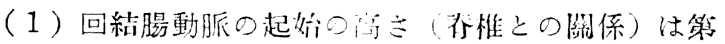
1 腰椎から第4婹椎の間に古るが，特に第 2 腰椎中止 $1 / 3$ 负ざ下方 $1 / 3$ 小ら出るものが多い。

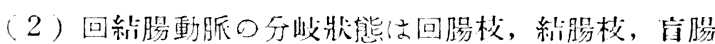

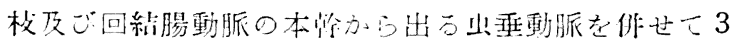
枝から 7 枝に分㪁学る。

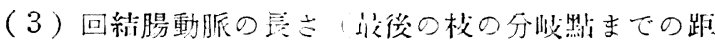
離）は $3.3 \mathrm{~cm}$ から $13.2 \mathrm{~cm}$ の間にある。

（4）回絬腸動脈の口膲页ざ壁厚は口膲 5 粍から 19 粍で, 壁厚注 $0.3 \mathrm{~mm}$ から $1.8 \mathrm{~mm}$ である。

（5）出垂動脈の數, 分㪁, 起始, 分有及び出垂の形

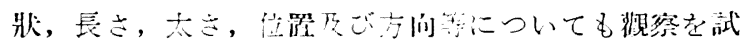
みた。

\section{（3）Froriep の神經篩について}

嵲尼教授指立尊

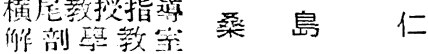

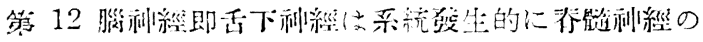
品上位のものが頭婄にとり入れられたものと考へられ

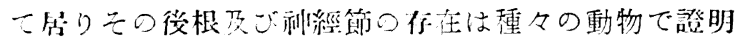
されてるう。乙かし人間についての登明は未だ不允分 であり Froriepは人胎兒については嘻載して居らず Streeter, Elze は小眙兒について Froriep の利

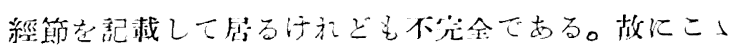
$=7 \mathrm{~mm}, 13 \mathrm{~mm}, 2$ 例只心゙ $17 \mathrm{~mm}$ の 4 例人胡兒で 見たFroriepの科繂節公説明す。

\section{(4) Ferritin 結晶化に就て}

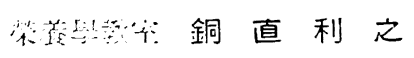

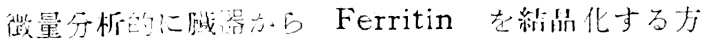

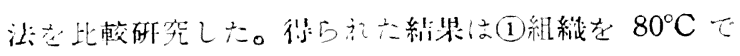

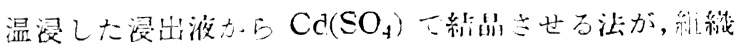

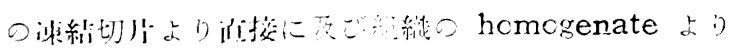




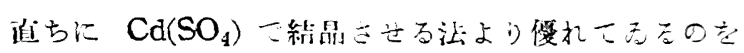
識つた。(2) $80^{\circ} \mathrm{C}$ 温浸による絬晶化の手段で, 結昆の 性状に及ぼす諸国了を检べた。(3)絬㫛数の算定による

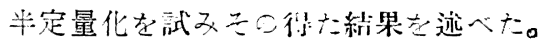

\section{（５）寛驗的瀉血性盆血時の䁍器鐵代謝 の研究}

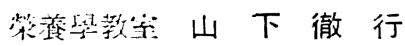

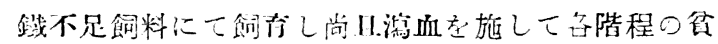

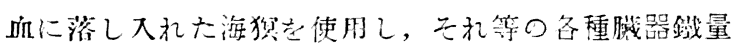
の消長を非つた。測定法は教守の全く新らしい践器鐡

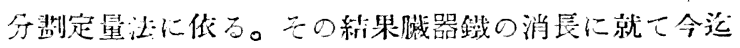

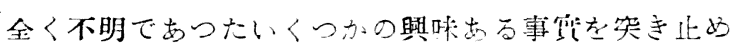
得たので報告する。

\section{（6）鐵吸收に關する碡究 IV}

\section{策荺學教空 吉 野 芳 夫}

前報に引繶き magnus の變法による保尘腸管澏流

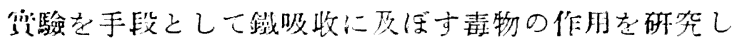
た。この際 $\mathrm{Fe}^{2+}$ 吸收将態々腸粘脱付 Ferritin 及ざ

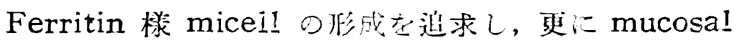

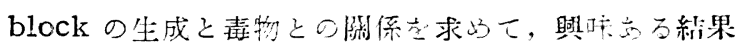
を得たので坏告さる。

\section{（7） $\mathrm{Cu}^{+} / \mathrm{Cu}^{++}$系酸化還元電位に對する Pyridine の影昆}

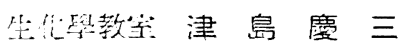

銅イオンの percxidase 作用结, pyridine 添加に二 依り增強されることが知られてるる。この pyridine

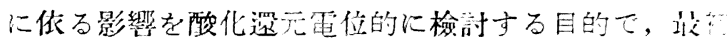
pyridine 添加に依る $\mathrm{Cu}^{+} / \mathrm{Cu}^{++}$采酸化還元電位の檤 化を追跡した。

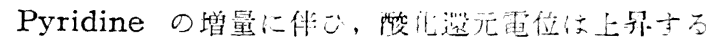

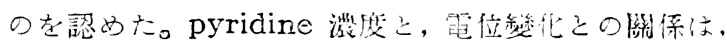

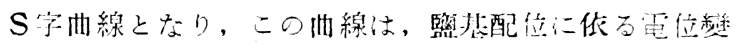
化の理諭式

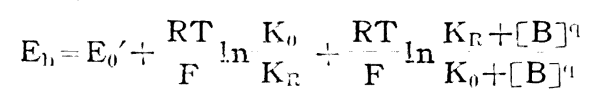

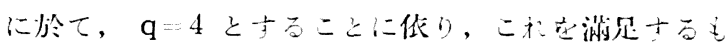
のである。極限電位として+0.3448volt 艼得た。次 に ascorbin 慢之 $\mathrm{H}$. 浴液を加へると, 利可一定の場合, pyridine の澳度

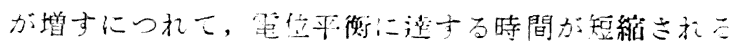

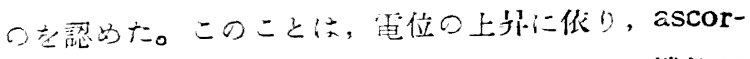
bin 酸- $\mathrm{H}_{2} \mathrm{O}_{2}$ 系の反想の mediator としての機能が 高まつたやうに一雄考へられるがこの采の反應に於

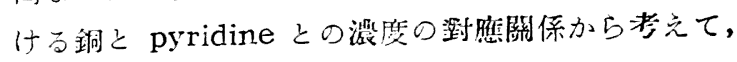

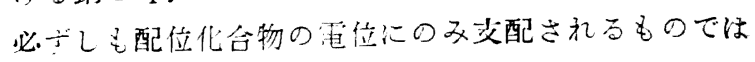
ない漛に思は礼る。

\section{（8) Cholinesterase 作用の熱力學}

\section{生化學教室 宿 谷 良一}

胁的球息清 cholinesterase による acetylcholine 分所反㫿について, つぎの如き反憅模式を提出 したが、こ礼等反㮣に齿する温照の影響について檢討 を问へた。

$$
\begin{aligned}
\mathrm{E}+\mathrm{S} & \rightleftarrows \mathrm{ES} \\
\mathrm{ES} & \rightarrow \mathrm{E}+\mathrm{P} \\
\mathrm{ES}+\mathrm{S} & \rightarrow \mathrm{ESS} \text { (不派性) }
\end{aligned}
$$

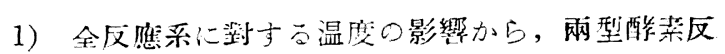
隼の温度係敖を求めた。

2) Michaelis 恒数の温度戀化から, 雨型醉素の醏

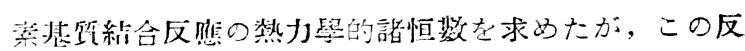
焦の entropy 蛙に正に得られた。この絬果は，

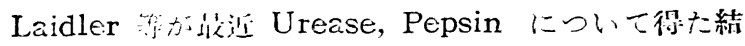
果之類似しており貽味ある䍐舜と思はれる。

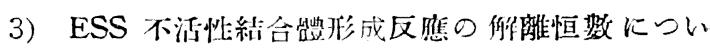

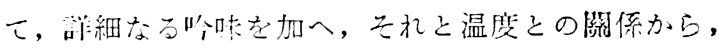
この反焽に於ける熱力䑁的諸崡数储を求好た。

\section{（9）溶血に關する㸴究}

$$
\text { 生理學教算小河 博 }
$$

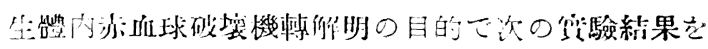
行亡。

1) 油酸ソーダ内溶血では, 血球敏・温度時間に力

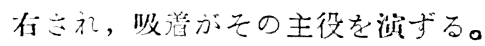

2）胉汒酸ソーダに依ると，吸着以外の因子が介在 してるるが，云の柡相隹 1)と似通つてるて，共に二 㪀の反怔の組合せを思わせる。

3） 1)2)に於下，血球が溶血を起さ奴程度に㫌らく

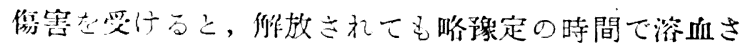
机吉。

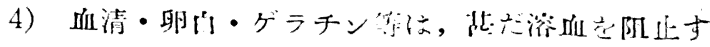
$\check{c}$

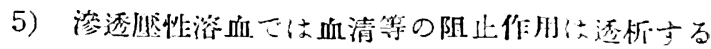
と消火し, 䖵地以外の作用と将へられる。 
6) フェニールヒドラヂン中毒家鬼で渗透然性抵抗 を兒ると，新生赤血球は，短時日の間に殆えど直線的 に, 平常抵抗に迄降下して整らく停涢し, 崩猿前短時 日で再び直線的に抵抗を火なつて，浴血する。

\section{（10）デスオキシコール酸寒天の食品檢} 查に於ける利用價值について 街生學教室 ○吉 澤 ひで 高 倉 剛 二

食品衛生檢查上大きな指樫となる大腸药の檢索のた めに, 遠藤培地・乳楉加ブイヨン・B.G.L.B醴醇管に 上る方法が現在使用されているが，我々はデスオキシ コール酸寒天による固形境養法を此等绵地と比較檢討 た加へた所, 腸内細菌に洋して特異な磞育をるたらす デスオキシコール酸ソーダの影響により，檢體からの 大腸菌の發現に好絬果をもたらし，集落の大きさ・色 調・數の點で遗藤䏴地よりもはるかに勝つており，こ

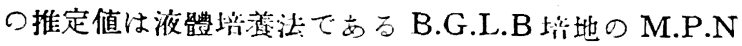
偭に接近する值を示した。又デスオキシコール酸ソー ダり持つ細莉抑制作用は涨染された食品检查物からの 大腸藏の檢出に有效なこと琶めた。

\section{（11）學童醴質指數に關する知見補遗}

\section{衛生學教等，桑 島 良 英}

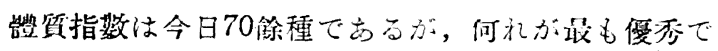
JIつ合理的で閵易な指数かを統計的に研究した絬果， ベルベック指数が最も學㳻に適合していることを, 年

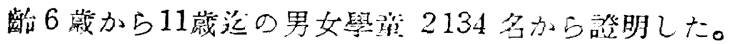

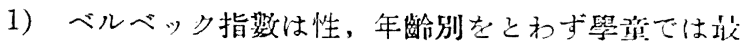
も合理的な優秀な指数である。

2）ベルベック指数と禹仙との關係るると此較的に 幽似の有哭とベルベック指数とは一致卞る。

3) ベルベック指荍と问性偏差做とは關倸は認められ 市い。

4) クレペリン作業檢疋とベルベック指數とは馀り相 關がない。

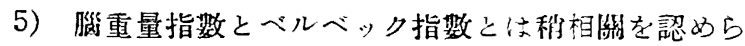
tis

（12）食品着色（黄色）劑特にオーラミ ンに關する食品悋生學的砰究

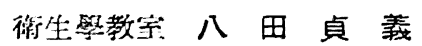
大 竹 作左衛門
オーラミン( $\left(\mathrm{CH}_{3}\right)_{2} \mathrm{~N}-(>\mathrm{NH}$

は現在食品着色剂上しての使用は禁じられているが，

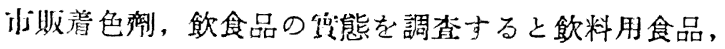
和落子, 洋莱子, あめ類等からこの種着色劑が檢出さ れ，特に䍝㡾では約 $80.2 \%$ の高率に認められた，そ こで检出率の主位を示した摆磨について，これの含有

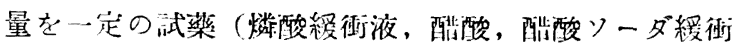

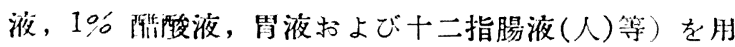
いて溶出しこの溶出液を光電比色計で比色定量してオ ーラミンの添加浮度を求めた。一方健常マウス及びウ サギを俱試動物として盄口投與法により急性中毒量を 量測しながら，同時にオーラミンを速續㣪口投與した ときの慢性中毒の發現狀態を健常ラッテを基として肉 眼的及び病理組䋨學的に究明した。

またウサギを用いオーラミンを迎縜摖口投與しなが ら,この間峘重の增減, 弦奇狀態に留意しつ〉, 赤响 球灭ざ白血球数の增減，血液沈降速度の推移，血液像 の質的，量的變要を究明し，更に色素刘（へパトサル

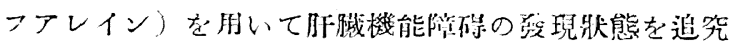
したのでこれらの成絬について述へた。

（13）肝動脈を結㮃して長期生存せしめ た犬の肝灆機能

樂理學教等: 今泉 守 雄

朋動脈胙校を絬柴された犬は約 $1 / 3$ は術後 4 日以内 に死亡すると云心。この原怕は腹水中に熟められる肺

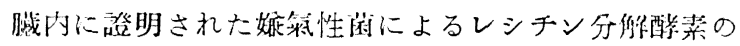
ためだとし，術後の Penicillin 使用により死の轉 機を䏚ぎ得ると云放。私は正常犬の胍動脈を絬禁し， Penicillin の注射により犬を元武に長期に门!生行

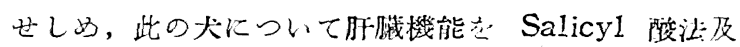
Santonin 法により检烃をなし, 正常犬の肺珹機能々 比較检㣙をした。この少数例に於ては雨检杳とも修り 継化はなかつた。然しこれによつて肝動脈絬紫犬の肺

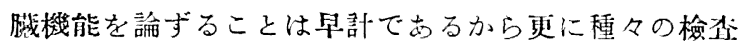

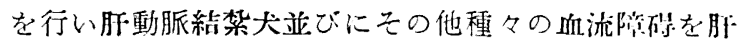

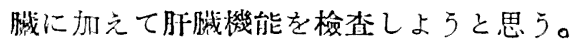

（14）旰苝と毛細管透過性との關係

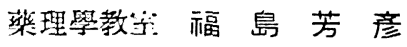

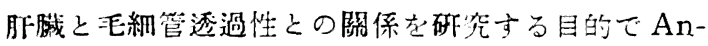


thenyの方法を用した。隊借得驗では $\mathrm{pH}$ は高い程

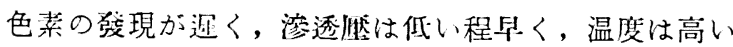

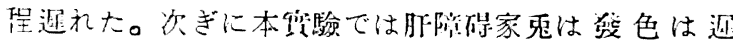
れ、肝剔出家鬼は全然碳色を認めなかつた，其原因と して考へられる事は 1)毛細管又は細動脈の收縮2)血 中色素の沾度3)血液成分と色素との吸着力の增大4)ク ロロホルムに溯する局所の感學麻病とである。此内血 中湠度は正常より肝剔の方が大であり，未梢感學麻歺 はトペルカミン」プ゚ロタイン」等でも独色するから雨 者共沼定出來る, 然るに朋剔の血清は正常の其れより は路後肢血管灌流法汅て血管收縮作用が強力である事 を念め，血清の色菜吸着力は朋剔と正常との間飞特别 の差罢は揌められなかつた。尚「アドレナリン」の漏

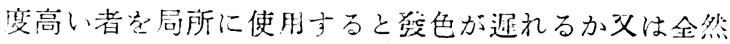

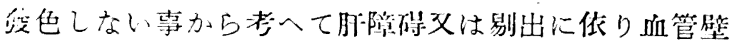

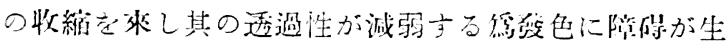
む゙ここてはないかと思は斿る。

（15）淋菌の培養法に關する砰究

都立吉原病院 田中英

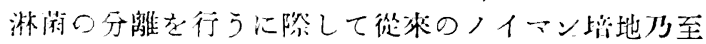
チョコレート寒天を肺いたのでは必ずしも良好な成緬

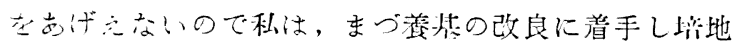

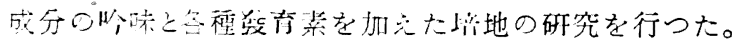

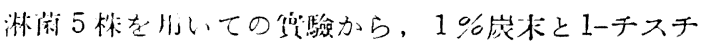
ン $0.1 \mathrm{mg} / \mathrm{cc}$ の割合に加况た妆近寒天 (肉水) 飞脱

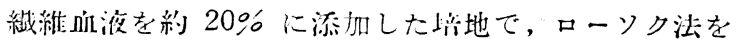

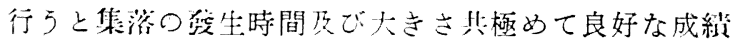
せ上げることがわかつた。

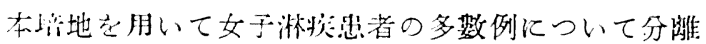

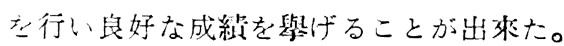

义，同一患者から「血液寒天」を跱!!! として，间時 に分滩㙅童を行い，本上消地の檢出率は「血液寒天」に 比べて遙かに良好であつた。

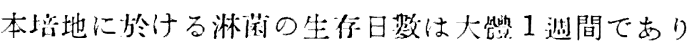
繼代字容易で南つた。

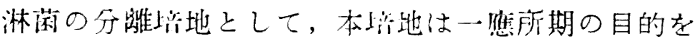
䤠することが出來たので铉にその概要を報告する。

（16）肺結核屍に於ける肺門部，氣管支周 圍, 氣管周園淋巴腺の組織學的研究

$\begin{array}{rlll}\text { 病理學教宝 丙 } & \text { 藤 } \text { 仁 } \\ & \text { 吉 } \text { 田 泰 }\end{array}$

栗粒結核拉 9 例，缦性肺結核 6 例，肺に絬核性病變
を認めざる 7 例計 22 例の上記淋巴腺を檢热した, 絬 論 1) Vは粟粒結核症殊に幼年者に多く慢性肺結核に 認められぬ。2)僈性肺結核の淋巴腺病變は叕粒結核拉 の夫れに比して弱い。3)淋巴腺病戀呈导る16例中同 一系統淋巴腺にTのみの戀化を呈するのが 2 例あり其 にTはすべて線維化してわた。活動性 Tは該淋巴腺义 は同一系統淋巴腺にD又はVを見る。4)同一系統淋巴 腺にDのみの變化は認められ奴。5) $\mathrm{S}_{\text {( }}$ は2 2 例に認め

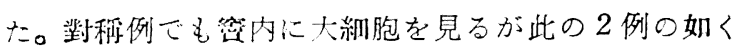
定型的ではない。1 例氣管文脑炎にやっ定型的な $\mathrm{S}_{G}$ を見た。6）Bh は16 例中 6 例に見た。いづれる線

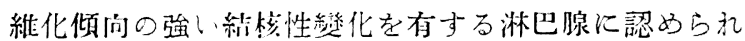

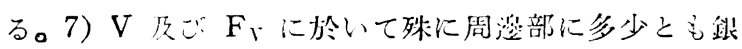
線維の增列学た。问䖝光法により絬核菌の分们を檢 菜中である。(略 $\mathrm{f} V \cdots$ 淋巴腺大部分乾酪化 $\mathrm{T} \cdots$ ‥限

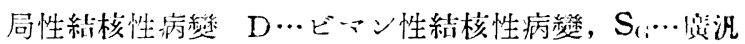
性箈内大細胞剥摊, Bh…細絧線維/硝子化)

\section{（17）結核症の血球凝集反鷹に關する砰究}

（特にッベルクリン陸性絬核应について）

\begin{tabular}{|c|c|}
\hline 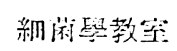 & 坂 本 行 \\
\hline & 山 崎 八 \\
\hline
\end{tabular}

從來ッベルクリン陰性絬核拝に就て，種々な袋驗的 角度より检吋な重放て来たが，今日は Middle-brook

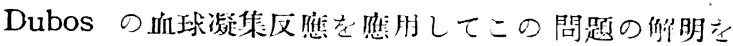
試みた。

即ち感作抗原としては, 結研製グリセリンブイョン より製した筫ツべルクリン，並に人型結核菌抽出ポリ サッカライドを抗原として行つた所，ッー反應除性絬 核拝にはツベルクリンを抗原とする時は總て㓌性に終 つたが，ポリサッッライドを抗原とする時は，可成り の陽性者を检出し得た。メハイドラジット使用患者に

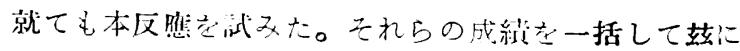
報告する。

\section{7 の追加}

中 村 敬 三

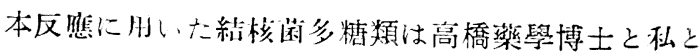
が協力して精製したもので電氣透析後アセトン分㔂立 行つたものであります。即ち極めて精製度の高いるこ でポリグリコサンがその本躀です。

（18）結核菌培養についての二三の知見

監炋检查所高 椋 卯 吉

野中芧




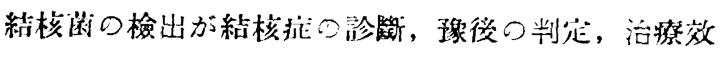
果の決定等に重要な意義を有する事は云う记もない事 である。

そこで絬核橉の检出法に就ては幾多の方法が所究き 礼て居る。

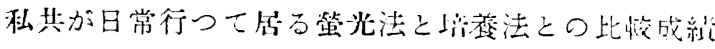
に就ての二三の知見を報告京る。

（19）肝剔出及び肝障碍家兔に經口投與し たアスピリンの尿中排泄狀沅に就て

\section{縚理學教空 小 形 昭 眞}

サリチル酸のAcetyl 化合踏であるアスピリン[以下 As と略]を肝剔出及び肝㜔硸家鬼に經口投與し，その

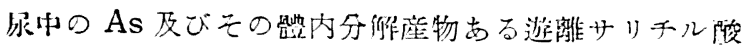

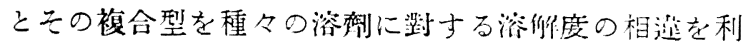

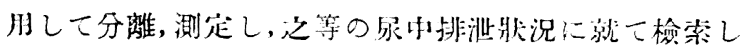
た。正常家鬼の瓜中に排泄されるサリチ儿酸の旅蜼及

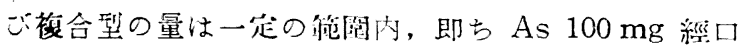

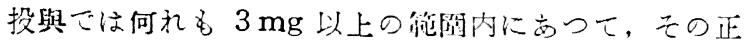
常筈图なるもの定める事が出来た。各種桨物による 肝藏障碍家鬼では複合か遊踓か何礼が゙此の符阔を逸 脱してらら。肝剔出の埸合は遊湤，複合其に著しく減 少し正常笵䦎を遙かに逸脱してるる。從つて本法によ り朋嚾機能檢查を行ひ得る見达が台るものと考へる。

（20）Heinz 小體形成について（第 2 報)

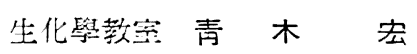

胁血球には一定の病的條件下゙で救々その内部に渆形 顆粒狀の小體が出現方ることが古る。Heinz 小能沈 三の一つで，從承乞の性贸について多歡の研究が尚る か，完全な説明は尚得られてわない。㷠に礼が hemoglobin の分解と關係ありや否やについては何等沈 定的な诃签が與へられていない。满者は特に二の點に 關心を持ち, phenyl hydrazineをはじめ種々の試洮

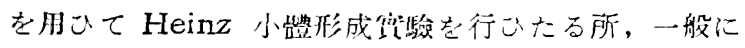
武驗管的に hemoglobin 分俳を來す栐な反隹系では いづれも Heinz 小體形成を認めるか～hemoglcbin

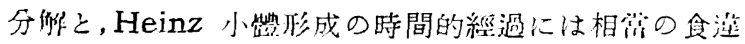
心があり，必ずしも雨者が一莪的心對照するとは㤎め られなかつた。家鬼について phenyl hydrazine 注射により極端な reticulocytosis を起させ reticulocyte と战然少血球との Heinz 小䠌形成を比皎 した前 reticulocyte では逝かに抵抗が強く，從つて

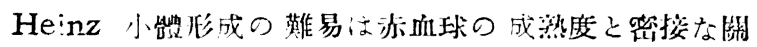

係を有することを甜こた。

\section{（21）Streptomycin 使用結核性䯣膜 炎の組織解副學碑究}

病理學教守（教授，木村哲二）

$\begin{array}{lll}\text { 吉 } \text { 井 } & \text { 隆 } & \text { 博 } \\ \text { 高 橋 } & \text { 篤 }\end{array}$

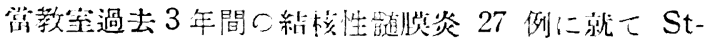
reptomycin (以下 St. My. と略) の影留老形態學的

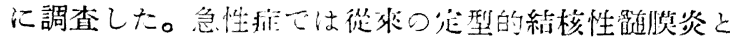
差黑を見ないが, 死しまでの經過证長するに從つて淅

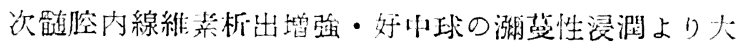

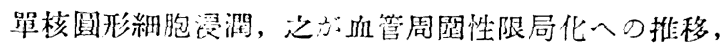
增列型絬核結節への進展並びに腦贷啠内への侵入。小 動脈内外脱の肥厚及線維等枪塞汇上る内腔閉塞等の戀 化を見，更に慢性化したものでは，高度の躍腔線維拉引

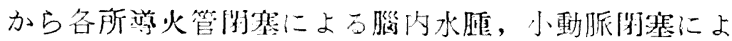

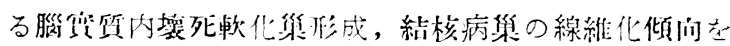
兒る。而して此所見は文脪では古るが St. My. 非 使用例で經渦著しく延镸したもの之形態的差思を認め

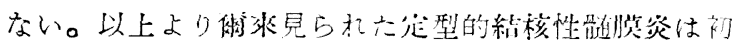
期急性期像に過ぎず，St. My. 使用に依り色段階の慢

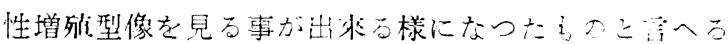

（22）Thorn test を中心としてみた ショック時血液所見

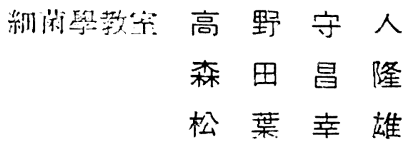

ショック時(アナフィキキシー，ヒスタミン,アセ チールコリン，ショック）血液所見に就ての研笢は多 いが，從來は何机も未梢血に就ての亲見の灭に研究の 焦點がそっがれていた。然し作ら日血球像，白血球数 の檢的は直接計算法に上るのが適法ですると唱兄られ

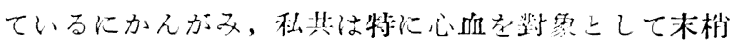
唓と對比して種々检就した。

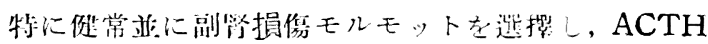

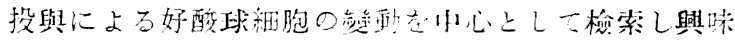

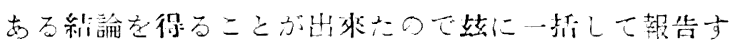
る。

（23）結核症の血中抗體について、第一報)

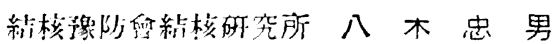

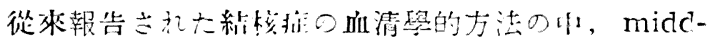




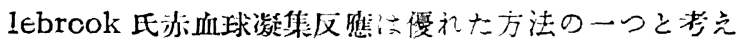
られ，今回はこの術式就㤦代䣸ッベルリリの問題を

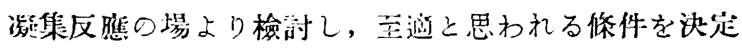
しこれに甚いて各種の集国に本反應を俊施し，その

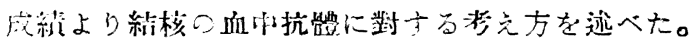

（24）眼科領域に於るコリネバクテリウ ムに就いて（第二報）

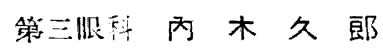

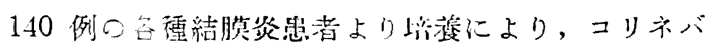

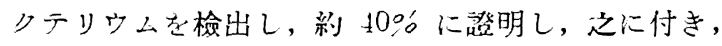

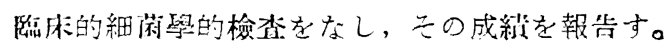

（25）蜜驗的髓膜炎の平流電氣感受性の 個體差について

第二小兒科岡田忠仁

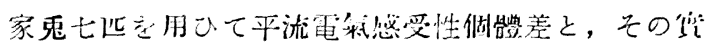

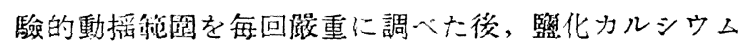
等五種類の㩰物の一定量を投與し，綎化の個體差を調 ベ, 关の二例の家鬼に於ては平流電武に可成り敏感に

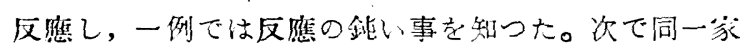

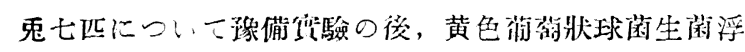

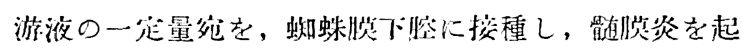
させ, 其の一般症狀及び白血球数, 體温, 能重と其に

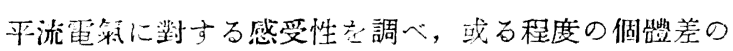
高ることを知つた。即ち巾二例に微接種後平流電氣與

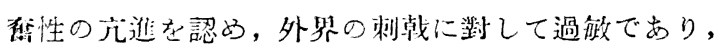
他の一例は特に反應の純いことを知つた。この樣に同

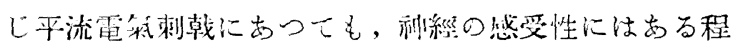

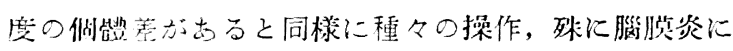

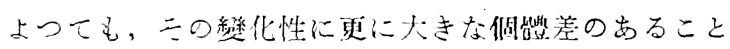
が楒めら礼天。

（?6）家鬼肝臟より Ferritin の祫出

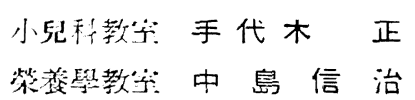

從來家鬼の朋㙎には Ferritin が舤いとされてるた

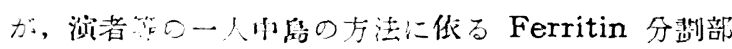
には相需量检出される。依つてこれ等の事福を㑇明す

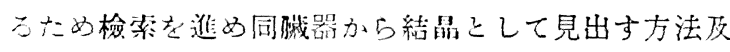
條件を诀分した。この榆出は只結晶化したと言ふたけ

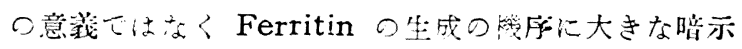
を與へろ點水重要で忍る。

\section{（27）抗菌劑長期使用小兒における頃菌症}

$$
\text { 第二小兒科太田秀 穗 }
$$

現在荙の小兒科领域に於ける落菌性将患の感染條件 に關しては娟力の消耗にその重點を路かれて芳えられ て來たのに踩し，抗菌療法が脣く使用されるに及えで

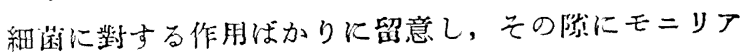

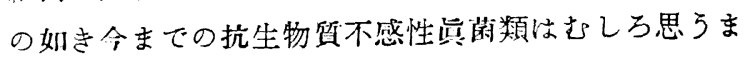

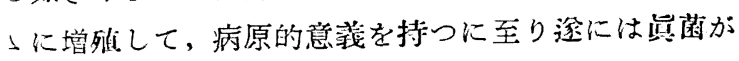
主要病状を呈する栐になる事が考方られる。現に近來 内外に於てとの栐な例の報告を度々見るし, 又我々は

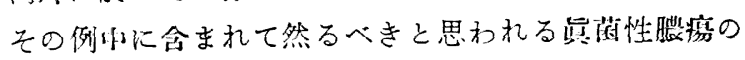
一例に非遇したので報告する。

\section{（28）イレウスの免疫血清學的砰究}

松倉外科 代田明郎, 代田克彦 野田 潔, 寺門正锫

染々はイレウス死因の本態に關してアレルギー的見

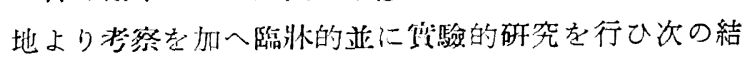
果を得た。

1)腸管の抗原性物貿として犬，芜乘及び人間の正常 並にイレウス腸管の漧燥抗原, 水酸化アルミナ吸着抗 原及びリポプロティンを用ひ抗原性に就て種々研究し た結果これ等諸抗原は動物の自家抗原たるを以て容易 に感作され難いが純粋な腸管抗原性物啠として抽出し たリボプロティンの頻回注射によつて強力なる抗體が 産出され家息灭び人間の正常並にイレウス腸管のいず れから製せられたり恣プロティンも抗原性に於て其通 性がある。

2)自家組緎成分として含有される腸管りか゚プロティ ンはイレウス時抗原として䈳液中に流出する。

3)，i）犬腸管りポプロティン兔茫家鬼血清をモルモ ットに静脈内注射すると定型的逆アナフィラキシー症 爿を呈して死しする。これは腸管りポプロティンと其

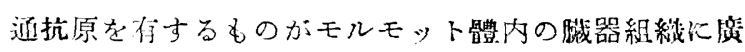
く你在しているためと思はれる。

ii）本抗血清飞就て各践器リポプロティンを抗原と して補踣結合反應を行らと何孔の埸合に於ても或程度 の反応か認められる。即各瀻器リポプロティンは抗原 性に於て共通性がある。

iii）犬腸管リポプロティン免将家鬼血清をモルモッ 卜に埆脈内注射すると定㤠的逝フナフィラキシーの括

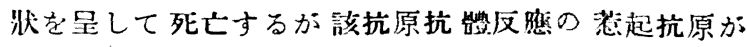


Forssman抗原そのものであるか否かに就て偝細なる 砳究を武之论の結果を得た。

a) Forssman 抗原を持た妨六及びラッテに本 抗血清妾静脈汋注射するとショック死を來たすこと は出來なかつたが可成り明確なショック症狀を墢現せ しめた。

b）モルモットの监淢及ざ腸管より製したリポイド

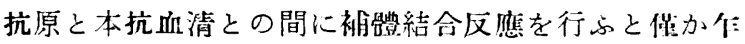
ら反悬が翏められる。

c）本抗血清は僅か伂ら溶血素を持つている。

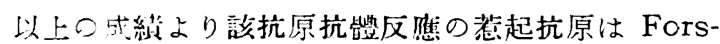
sman 抗原三のものとは認め難いがそうかと云つて全 く罢るきことは云ひ切机ず尚この點に就ては目下研究 中である。

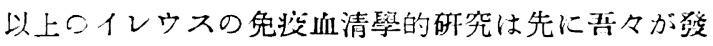
表した如くイレウス時に於ける血清並に腹水中の有效

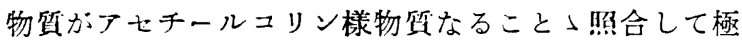
めて舆味深く,イレウス死因の本態として自家組䋨成 分とし二含有さる腸管リポプリティンを抗原とする自

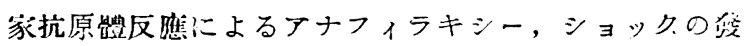
來性を示唆衣るものと思考される。

\section{（29）イレウスショックの病理組織學的 研究}

\section{松公外科 山崎泰弘, 井上善夫 今井 勲, 井出裕雄}

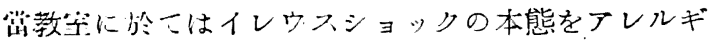

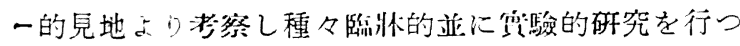
て來た放私其は本研究の一環として病理組織學的檢索 を行ひ二，三の知見を得たので茲化報告する。

1.ショック死を來した腸管リポプロテイン免没家死 の病理組総藇的研究

腸管抗性物犋として犬，家曱及び人間の正常並に1 レウス腸笵乾燥抗原, 水酸化アルミナ吸着抗原及びリ ポプロテインを用ひ， $2.5 \mathrm{~kg}$ 前後の家鬼に就いてアナ フィラキシーショック發爽の有焎を檢したところ, 之 等諸抗原は動物の自家抗原たるを以て何れ飞於ても殆 んぞショック症狀は認められなかつたが純料なる腸管 抗原性物啠として抽出されたりポプロテインの頻回注 射免收家象翡に於ては該抗原の再注射によつて激しい ショック拉狀を呈し死しした鹳例を經驗した。之等家

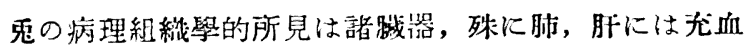
高度て組䋨祭的には特に㸬に病變著明で血行靜止，浮 䛲, 义をこうにより胋胞肉出血を認め, 血管, 氣管艾

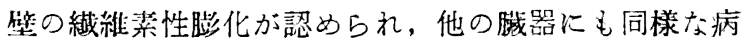
曫を認める。即ち䑏器全般に初期のアレルギー性病變 と考へられる所見の發現が認められた。

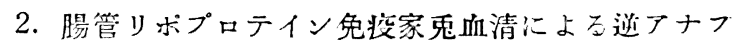
イラキシーに關する病理組織學的研究

犬腸管リポプロテイン免度家鬼衁清 $0.5 \sim 1.0 \mathrm{cc}$ 卆 モルモットに静注すると抗體霞の高い血清では定型的 逝アナフィラキシー症状を呈し死しした。該モルモッ 卜の病理組織學的所見は鼻腔，口悾に赫袿色泡沫性糊 液を无し肺瀻は著しく脸化して表面喑赫色の浴恤斑を 認め割面よりは多量の泡沫狀液を出し浮䏨狀態が極め て顯著である。

組䋨學的には肺淢殊に病變著明で高度の血行埆止，

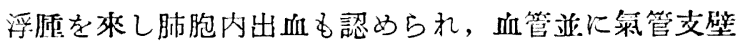
周阙の䋐維素性兴化を呈しており, 之の他, 肝飞於け

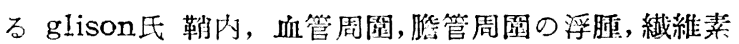
性脤化, その他, 紧腸等他の瀻器に於ても同栐な初期ア レルギー性病變と思はれる所見が喼められた。即ち腸 管リボプロテインと共通抗原を有するものがモルモッ

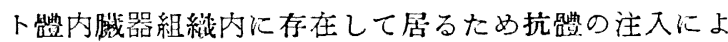
る逆アナフイラキー現象を呈したものと考へられる。 以上の所見はイレウス免狻衈清學的研究と照合して腸 管リポプロテインによつて杞つたアレルギー性病變と 㑡せられイレウスショックの本態として腸管リポプロ テインによる自家抗原抗㕨反應によるアナフィラキシ ーショックの筑来性を示侁するもの上思将される。

（30）氣管支肺容量檢查法に關する砰究 （其の四）臨床的觀察

$$
\text { 第三开盘斗 宮 崎 鬼 - }
$$

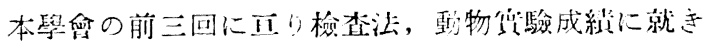

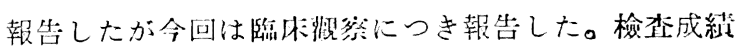

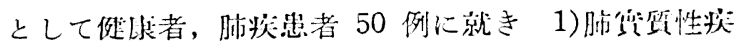

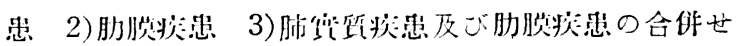
るものとに大別すると夫々特有な測分值を示した。即

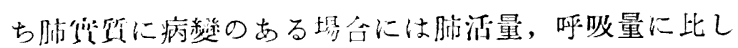
酸染消热量の減少が著明となり，肋膜粐患殊に肥厚疾 着或は脲胝形成は肺活量の著しい減少を来しているが

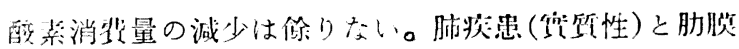
为患を合併せるものは去々の混合した所見を示した。

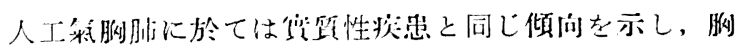

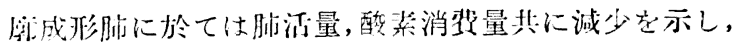

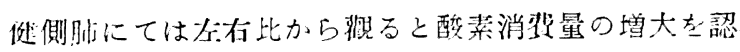

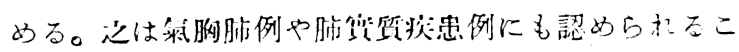




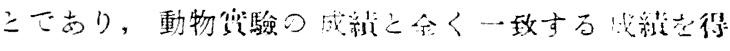
た。即ち肺楼能の代償出現には酸㜪消势量の著明な影 綮が南ること老知つたのである。

\section{（31）氣腦法に於ける蝸牛殼導入管の通 氣性に就いて}

\section{开鼻叫喉科 稻 葉 節子}

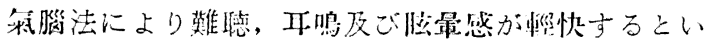
う臨床的事空は早くから報告されている。しかし年の 作用機轉に關しては不明の點が多い。蝓牛惩導水管を 通してての内耳の影響が重要なものの一つと帣光られ ているが, 後藤は煎水管を迎つて内耳内へ空氣が進入 するという假説を發表している。しかし嘪驗的に證明

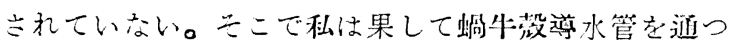
て内耳へ等氣が進入するものであるか否かを繁明立べ く家鬼を用いて筑驗を行つた。家鬼に於ては空氣とり コールとの罞換が十分に行われた際，時として内监へ 空氣が僬入するものである事を確めた。目つその近路 㳊蝸牛殸学水管で志る事を电證明する事が出來た。

（32）人耳管液體排泄機能に關する臨牀

\section{賈驗的破究（第一報）}

$$
\text { 策一耳鼻科 深 町 正陽 }
$$

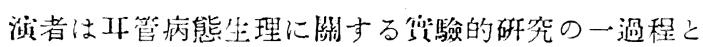
乙て,开管排泄作用の臨朴的意莪の大なることを認め，

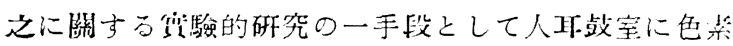

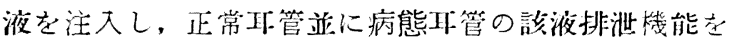
鼻腔内上り淮然し，正管排泄能に關する一二の所見を 得たので報告する。本贷驗により耳管の常態及病態に 於ける排泄機能の一部を認知し得ると同時に次の事垈 声知り得た。

1)耳管の液能排泄は物理條件或は开管竹作用による のみならず，耳管粘㬴上皮線毛迎動电與兑て大なるも のむること。

2) 正常人中开腔に注入せる液は通常 10 分前谈にし

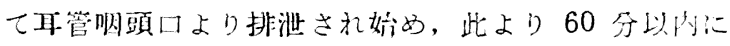
排泟を終了する事。

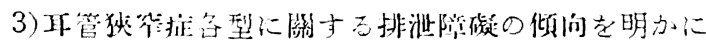

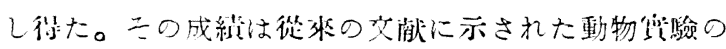

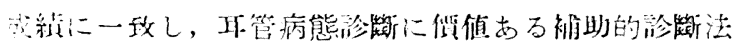
でると考へる。

（33）カラアザールの一例（2）

行徳内的 倉 持 正 男
患者は 32 祴の男于。㹦和 17 年より北艾, 中菠,

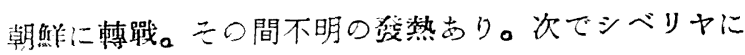
抑留され，22 年 6 月毁還。衰弱茫しきため, 深草國立 病院に入院し，胸骨第刺に上り,「カラアザール」と沴 断され，大藏病院に轉这されて 23 年 5 月治瘾退院す。

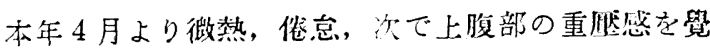
完，8月18日本内科に入院す。

入院時蜰臟の下界は中線上脂より 2 横指經下。右界 は中線より4横指右。左与は左中腋䠛線上飞て朌骨马 と交汉す。米梢血及び购骨等刺液よりは㤝見出來ざる も，肺践穿刺により、「リーシュマニア・ドノバニー」 を證明し、「カラアザール!と兴斷す。五偠の「アンチ モン」製劑「「ネスボサン_の注射により，脖の下，4

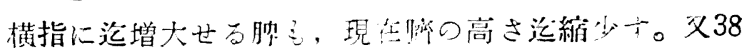

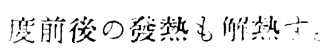

\section{（34）兩側下肢, 腦, 肺及腎等に殆ど同 時に栓塞を起した心藏辨膜症の一 例 (3)}

\section{行德讨 松 坂 七 郎}

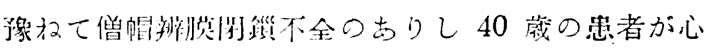
淢状熊少し婜化して, 浮脾, 呼吸困難, 等現はれかけ

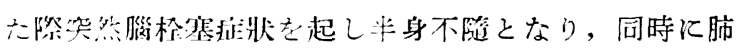
や俭瀻にも枪塞掟狀を起して肺ては打診上及び聴診上

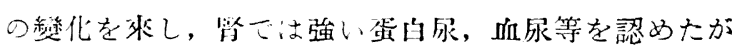

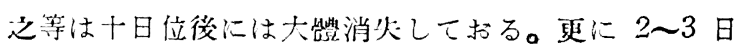
後には\%側下肢に, 次で右側下荕にも股の着け根から

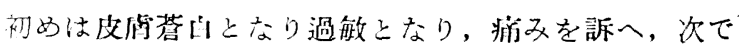
紫色を洲じ，阔もなく大なる紫斑を生じ，多数の水泡

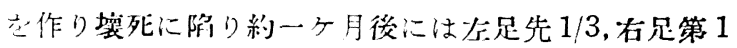
指汶颃性塆死となつて、治つたものにつき報告する。

\section{（35）大腸菌屬及之の類似菌の産生せる 「ストレプトマイシン_破壇物質に 關する䂧究 (1)}

\section{行復拍吉田利雄, 松坂七郎 牛山淸司, 千葉品雄}

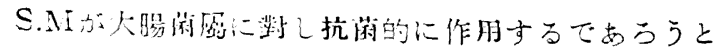

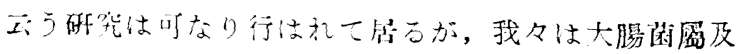

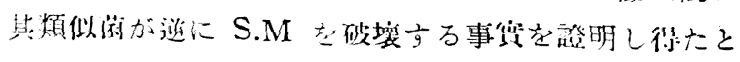
思的ので此に临する研究につき報告する。

1、注射した S.M つ一部が腸内に分泌され、文は流

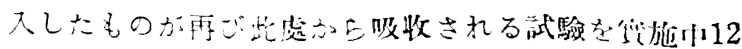


指腸内に注入した S.M は其排泄量, 各膱器及組織内 沈着量を合算推定するも注入量に比し, 高單位のS.M が腸管内に於て消火する。

2. リンゲル氏液に puffer 液を混じて PH 7.2 と し恒温槽内に於て小腸, 大腸, 葓便を入れ S.M の破

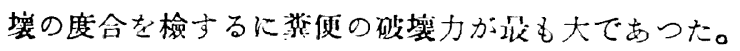

3. 䊝便中に存すると思心数種の菌類を塔着 3 日後 「シアンベラン」で滤過し，愬液につき略驗をなすに 綠继莉の S.M を破㳖する力は最も大であり， B.C. Comnunior は留子微力であつた。目下我は此作用本 態が哹关で古るか否かを明かにせんとして遍求中であ る。

\section{（36）姙娠中毒症殊に子㿈に關する血清 學的䂰究}

\section{第二産㖊人科 岡 本 俊 美}

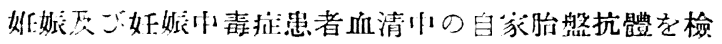
索するため, 胎盤より抽出した, 高柄二表, 三法變法, 四表物贸，加來氏 H.P.S，K.P.S を抗原とし，妊婦， 妊娠中毒症, 踏照として偨康男子及心゙子宫癌患者血清

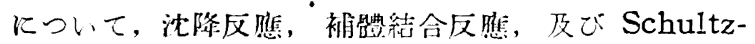
Dale 氏反悲を行つたが，乙の結果を䋡合すれば，之

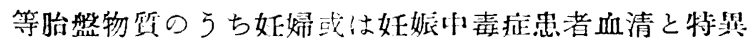
的に反碓すると思はれたものもあつたが，血清の例教

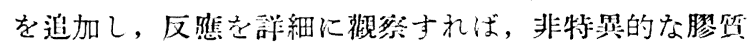
不安定反照に依るものの如く思は礼, 之等胎盤物啠に

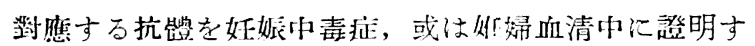
ることが出來なかつた。從つて一部の堅者の言う樣な 姖始中毒症は抗原, 抗镪が關與する园のアレルギーで あると断定する説に筫成するには一考を要すると将兑 ざるをな微いのである。

\section{0 に對する質問}

\section{國立解生試噞所 功刀博}

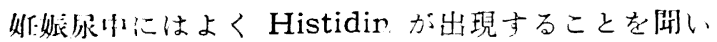
たがこれについて何か關係はないでしょうか。

\section{6 の質問に對する答辯}

本研究は熊本祭大加來教授の「姖娠中毒拝は胎盤物 質を抗原とする抗原抗體反奀に依る鿓のアレルギーで ある。との説に龂する反論の一根㨡となするのであつ て, 問者のヒスチヂンと妅脈中毒扰との關係如何と云

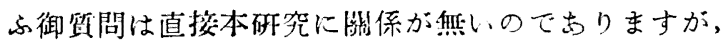

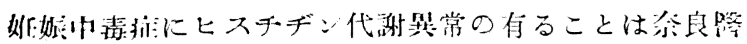

犬足高教授の強調する所で, 教室研究生高橋氏仁依六

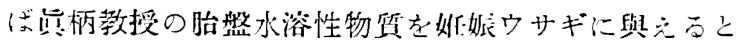

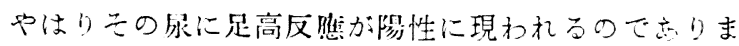
す。

\section{（37）胎盤水溶性物質に依る妊娠家兔肝 の病理組織學的矿究}

\section{第二産婦人科 稻 垣 惠 三}

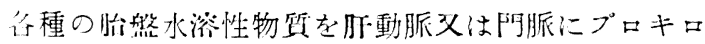

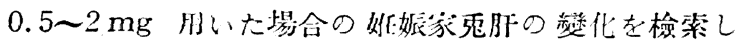
たが，ての結果は小莱を單位として墢生する㳖死が主 要所見であり，その程度は P.P が聶も弱く，P.R は 小等度で, P.S は極めて強い。塯死は主とし凝固㙥死 であつた。无この壤死部には細胞浸潤，色菜沈着など が見られた。文都脈枝内に血烃形成を認め,この部の

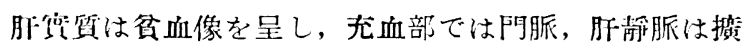
张し管腔は无洲し，毛細管も著明に援大し肝細胞装を

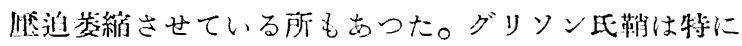
強い檤化はないが細胞浸潤が著明であり，脂肪戀性は 坮死の周渗に特に強く鉴彇に存在した。又線維素の析 出は壤死巢周湟の細胞索間に沿つて放線狀に強く出現 した。

なお組紋學的所見ではP.R に依るものが奶㚴小毒

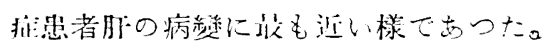

（38）內腦水腫の二例

$$
\begin{aligned}
& \text { 東京都監察隥務院 河野林 } \\
& \text { 病理學教室下條藤一 }
\end{aligned}
$$

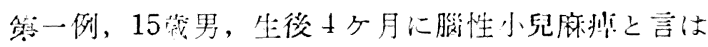

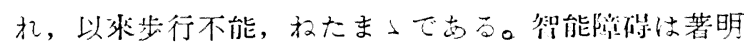
でない。(但し本屍妹はけ粇)。死亡 2-3 日前より食

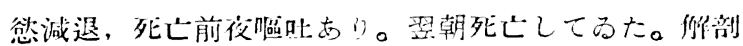
時身長 $155 \mathrm{~cm}$, 䙫重 $44 \mathrm{~kg}$, 腦重量 $1500 \mathrm{~g}$, 颚阔は略 蕁常, 頭型は上下にや〉長い。高度内腦水胞, 特に左

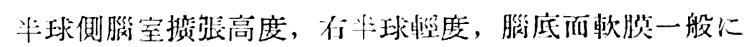

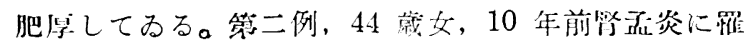
り，1ヶ月位で治つたが以後四肢脱力感強く，更に小

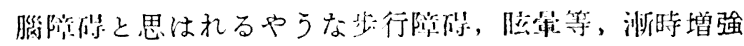
し, 死亡半年前より, 燕下困蜼上なり誤领, 咳か烈し

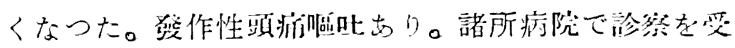

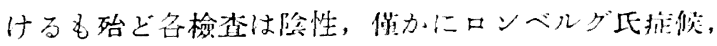
ババンスキー氏㑡微候が陵性で古つた。此等二例に就 て病理學检索の一部を報告する。 